Ani Saskia, Jumiatil Efektivitas Program Sanitasi Berbasis Masyarakat dalam Meningkatkan Derajat Kesehatan Masyarakat

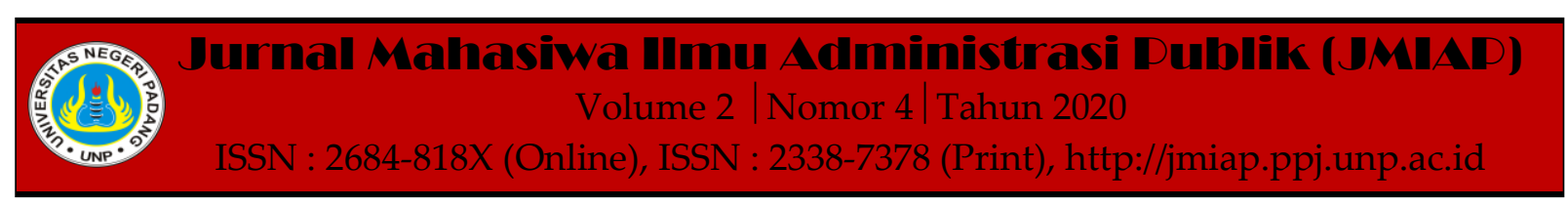

\title{
EFEKTIVITAS PROGRAM SANITASI BERBASIS MASYARAKAT DALAM MENINGKATKAN DERAJAT KESEHATAN MASYARAKAT
}

\author{
Ani Saskia ${ }^{1(a)}$, Jumiati $^{2(b)}$ \\ ${ }^{1}$ Jurusan Ilmu Administrasi Negara, Universitas Negeri Padang \\ ${ }^{2}$ Jurusan Ilmu Administrasi Negara, Universitas Negeri Padang \\ a)anisaskia80@gmail.com, ${ }^{b)}$ jumiati@fis.unp.ac.id
}

\begin{abstract}
This research is motivated by the benefits of the establishment of the sanimas program facilities, namely improvements in terms of increasing the degree of public health, improving the quality of sanitation and environmental hygiene of the community. This study aims to describe the effectiveness of community-based sanitation programs in improving community health status in Korong Padang Manis Nagari Campago, V Koto Kampung Dalam Subdistrict, Padang Pariaman Regency. This type of research is qualitative using descriptive methods. The research was conducted in Korong Padang Manis, Nagari Campago, V Koto Kampung Dalam, Padang Pariaman Regency. Informants are determined by purposive sampling technique. The data used in this study are primary data and secondary data. The data was collected by means of interviews, observation and documentation study, with the validity test using source triangulation. Meanwhile, the data analysis technique is done by reducing data, presenting data, and drawing conclusions. The results showed that the effectiveness of the community-based sanitation program in improving the health status of the community in Korong Padang Manis was not yet effective. This is because the public's awareness is still low on maintaining the cleanliness of the environment for the infrastructure of the sanimas program and there are still people who throw garbage and defecate in the open.
\end{abstract}

Keywords : Effectiveness Program, SANIMAS Program, Public Health

Corresponding author. Email. anisaskia80@gmail.com

How to cite this article. Saskia, A \& Jumiati. (2020). Efektivitas Program Sanitasi Berbasis Masyarakat dalam Meningkatkan Derajat Kesehatan Masyarakat. Jurnal Mahasiwa Ilmu Administrasi Publik (JMIAP) Jurusan Ilmu Administrasi Negara Fakultas Ilmu Sosial Universitas Negeri Padang, Volume 3 (2), Hal. 115-122.

http://jmiap.ppj.unp.ac.id

ISSN : 2684-818X (Online), ISSN : 2338-7378 (Print)

Copyright@2020. Published by Labor Jurusan Ilmu Administrasi Negara FIS UNP, Padang 


\section{PENDAHULUAN}

Sanitasi adalah suatu usaha untuk membangun sebuah sarana prasarana dengan tujuan meningkatkan derajat kesehatan masyarakat, terutama dalam mengurangi jumlah penyakit yang dapat menular melalui air dan lingkungan. Berlandaskan Undang-undang nomor 23 tahun 2014 tentang pemerintahan daerah, pemerintah daerah bertanggungjawab penuh dalam memberikan pelayanan kepada masyarakat yaitu pelayanan air minum dan sanitasi (Undang-Undang, 2014).

Berdasarkan pada peraturan presiden republik indonesia no 185 tahun 2014 mengenai Percepatan penyediaan air minum serta sanitasi pada pengelolaan air limbah rumah tangga. Sanitasi adalah cara yang dilakukan supaya terbentuknya keadaan yang memenuhi syarat kesehatan dengan membangun sanitasi.(PerPres, 2014).

Adapun akibat dari rawan sanitasi pada suatu daerah menyebabkan salah satunya penyakit diare yaitu pencemaran yang diakibatkan oleh kotoran manusia dapat bersumber dari virus, bakteri dan patogen lainnya. Pence, aran dapat melalui air, tanah, lalat, dan tangan. (Hasanah, 2018).

Di Indonesia, masalah sanitasi relatif tertinggal, masih banyak masyarakat yang belum memiliki saluran sanitasi yang memadai. Dalam menanggulagi masalah sanitasi pemerintah membuat kebijakan masalah sanitasi yaitu Program SANIMAS.

Program SANIMAS adalah program diselenggarakan oleh Kementrian PU yang dijalankan oleh dinas PUPR Kabupaten/Kota terkait hal memperbaiki rawan sanitasi dengan cara memberikan sarana prasarana pada sanitasi perihal penindakkan air limbah kawasan permukiman penduduk yang berpenghasialan minim dikawasan permukiman kumuh, padat penduduk, dan rawan sanitasi.

Program sanimas diatur dalam surat edaran Direktorat jnederal cipta karya nomor : 03/SE/DC/2020 mengenai pedoman teknis pelaksanaan kegiatan padat karya. Dinas PUPR bidang cipta karya Kabupaten padang pariaman yakni menjalankan sesuai dengan kementrian pekerjaan umum dalam menjalankan program sanimas berdasarkan buku petunjuk teknis SANIMAS Reguler Tahun 2017.

Program sanimas memakai prinsip demand responsive Approach (DRA) ataupun pendekatan respon kebutuhan. Pemerintah kabupaten dan kota wajib menyatakan kehendak terlebih dulu jika tidak tentu tidak akan diberikan fasilitas. wujud minatnya yaitu kesediaan mengalokasikan dana APBD. perihal tersebut sama dengan prinsip pendanaan sanimas yang menggunakan multi sumber. Tidak hanya itu sanimas pula memakai prinsip seleksi mandiri, pemilihan teknologi sanitasi, partisipatif dan pemberdayaan.

Program sanimas disumatera barat bisa dikatakan masih kacau sebagaimana diberitakan melalui berita online merdeka.com (Kamis, 19 Oktober 2017 14:27) Heri Nofiardi yang membawahi kelompok kerja sanitasi mengatakan mengejar ketertinggalan sanitasi dengan cara mengilangkan kebiasaan masyarakat BABS. Tahun 2017, target akses 19 Kabupaten/Kota di Sumbar berbeda-beda. Paling tinggi untuk kota Bukittinggi dengan target 96 persen. Kemudian, Kota Solok 95 persen, dan Payakumbuh 95 persen. Sedangkan Daerah dengan target masih rendah antara lain, Kabupaten Solok, hanya 25 persen, Solsel, 28 persen, Mentawai, 31 persen, Pasaman, 31 persen, dan Padangpariaman, 32 persen. Kondisi seperti BABS juga diakui gubernur sumbar Irwan Prayitno, menurutnya,lamanya proses penuntasan masalah sanitasi tidak terlepas dari karakter, budaya dan kebiasaan masyarakat Sumbar sendiri. Sehingga, tidak merasa enggan terus merawat kebiasaan buang air besar, mandi di kawasan Sungai. Bahkan, di bandar bekali Kota Padangpun, masih banyak ditemukan kebiasaan tersebut. Untuk mengurangi jumlah masyarakat yang BABS, perlu digencarkan 
kegiatan sosialisasi. Sebab, persoalan BABS tidak semata soal kebersihan lingkungan. Namun, juga masalah kesehatan. Sehingga, memberikan pemahaman tentang perilaku hidup bersih perlu terus ditingkatkan. Irwan menilai, PPSP sangat diperlukan, apalagi, di Sumbar realisasinya cukup lamban. Padahal, dalam mewujudkan pembangunan sanitasi permukiman, telah ada anggaran yang dikucurkan dari pusat melalui Dana Alokasi Khusus (DAK), anggaran dari Provinsi dan Kabupaten/Kota.

Kabupaten Padang Pariaman telah melaksanakan program sanimas tiap tahunnya. di Kecamatan V Koto Kampung Dalam pembangunan sanitasi air limbah sangat terbatas karena kurangnya anggaran biaya dari pemerintah, masih banyak tempat yang belum diberdayakan dengan pembangunan sanitasi tersebut. Kepadatan penduduk yang terus meningkat tidak berbanding lurus dengan pelayanan sanitasi.

Korong padang manis merupakan tempat dilaksanakannya program sanitasi berbasis masyarakat (SANIMAS) yang sudah berjalan beberapa tahun yang lalu. korong padang manis menjadi wilayah yang memiliki masalah air limbah domestik.

Adapun permasalahan Program Sanimas di Korong Padang Manis Nagari Campago adalah Hanya sedikit masyarakat yang mau menggunakan sarana dan prasarana dari sanimas, dan juga masyarakat masih banyak yang belum mengetahui dengan adanya program SANIMAS, selain itu masih ditemukan masyarakat yang membuang sampah dan buang air besar sembarangan dan Kurang terawatnya bangunan setelah dibangunnya sarana sanitasi tersebut

Berdasarkan permasalahan yang ada peneliti ingin melihat Bagaimana Efektivitas Program Sanitasi Berbasis Masyarakat (SANIMAS) Dalam Meningkatkan Derajat Kesehatan Masyarakat Di Korong Padang Manis Nagari Campago Kecamatan V Koto Kampung Dalam Kabupaten Padang Pariaman.

\section{TINJAUAN PUSTAKA \\ Efektivitas}

Berdasarkan Kamus Besar Bahasa Indonesia/KBBI, kata efektivitas berasal dari kata yaitu efektif yang mengandung arti dampak, efek, dan akibat yang ditimbulkan.

Kata efektif berasal dari bahasa inggris yakni effective artinya berhasil atau tidaknya ataupun sesuatu hal yang dilakukan dengan sukses. Dalam kamus ilmiah kata efektivitas sebagai kesesuaian penggunaan, hasil penggunaan atau tujuan pendukung. Efektivitas adalah elemen utama dalam mencapai tujuan yang sudah ditetapkan pada sebuah organisasi. Apabila dikatan efektif jika tujuan atau sasaran dapat dicapai sesuai dengan apa ditetapkan sebelumnya. (Rosalina, 2012).

Menurut Dunn mengungkapkan bahwa: Efektivitas berkaitan dengan apakah suatu alternatif mencapai tujuan yang diinginkan atau sebaliknya dari pengambilan sebuah tindakan. (Dunn, William, 2003).

Selain itu efektivitas juga dikemukakan oleh The Liang Gie dalam Halim (2004) efektifitas adalah suatu keadaan yang terjadi sebagai akibat yang dikehendaki kalau seseorang melakukan sesuatu perbuatan dengan maksud tertentu dan memang dikehendakinya, maka orang itu dikatakan efektif bila menimbulkan akibat atau mempunyai maksud sebagai yang dikehendakinya.

Hal ini menunjukkan bahwa indikator efektivitas dalam hal pencapaian tujuan dan sasaran yang telah ditetapkan merupakan ukuran dimana suatu tujuan telah mencapai sesuai rencana.

Adapun kriteria atau ukuran mengenai pencapaian tujuan efektif atau tidak, sebagaimana dikemukakan oleh Gibson dalam Tangkilisan (2005), efektivitas dapat diukur sebagai berikut :

1) Kejelasan tujuan yang hendak dicapai Hal ini bertujuan agar karyawan dalam pelaksanaan tugas mencapai sasaran yang terarah dan tujuan organisasi dapat tercapai.

2) Kejelasan strategi pencapaian tujuan Strategi adalah "pada jalan" yang 
diikuti dalam melakukan berbagai upaya dalam mencapai sasaran-sasaran yang ditentukan agar para implementer tidak tersesat dalam pencapaian tujuan organisasi.

3) Proses analisis dan perumusan kebijaksanaan yang mantap Hal ini berkaitan dengan tujuan yang hendak dicapai dan strategi yang telah ditetapkan, artinya kebijakan harus mampu menjembatani tujuan-tujuan dengan usaha-usaha pelaksanaan kegiatan operasional.

4) Perencanaan yang matang Pada hakikatnya berarti memutuskan sekarang apa yang dikerjakan oleh organisasi dimasa depan.

5) Penyusunan program yang tepat Suatu rencana yang baik masih perlu dijabarkan dalam program-program pelaksanaan yang tepat, sebab apabila tidak, para pelaksana akan kurang memiliki pedoman bertindak dan bekerja.

6) Tersedianya sarana dan prasana Salah satu indikator efektivitas organisasi adalah kemampuan bekerja secara produktif. Dengan sarana dan prasarana yang tersedia dan mungkin disediakan oleh organisasi.

7) Sistem pengawasan dan pengendalian yang bersifat mendidik. Sistem pengawasan dan pengendalian yang bersifat mendidik mengingat sifat manusia yang tidak sempurna maka efektivitas organisasi menuntut terdapatnya sistem pengawasan dan pengendalian.

Untuk mengukur efektivitas pada Program sanitasi berbasis masyarakat dalam meningkatkan derajat kesehatan masyarakat digunakan standar pengukuran yang dipaparkan oleh Budiani dalam (Primanda, 2017) yaitu :

1) Ketepatan sasaran program yaitu sejauhmana peserta program tepat dengan sasaran yang sudah ditentukan sebelumnya.

2) Sosialisasi program yaitu kemampuan penyelenggara program dalam

$\begin{array}{lcr}\text { melakukan } & \text { sosialisasi } & \text { program } \\ \text { sehingga } & \text { informasi } & \text { mengenai } \\ \text { pelaksanaan } & \text { program } & \text { dapat }\end{array}$
tersampaikan kepada masyarakat pada umumnya dan sasaran peserta program pada khususnya.

3) Pencapaian tujuan program yaitu sejauhmana kesesuaian antara hasil pelaksanaan program dengan tujuan program yang telah ditetapkan sebelumnya.

4) Pemantauan Program yaitu kegiatan yang dilakukan setelah dilaksanakannya program sebagai bentuk perhatian kepada peserta program.

\section{Program Sanitasi Berbasis Masyarakat (SANIMAS)}

Program sanimas adalah program yang menyediakan sarana dan prasarana sanitasi berbasis masyarakat dalam pengelolaan air limbah. Program sanimas menggunakan pendekatan pemberdayaan masyarakat dengan cara: 1. Memotivasi keberpihakkan kepada masyarakat berpenghasilan rendah, 2. Memotivasi partisipasi masyarakat, 3 . Menggerakkan inisiatif kelompok dengan keadaan keterbukaan, 4.Menambah kemandirian masyarakat, 5. Penguatan kinerja masyarakat (Kementerian Pekerjaan Umum dan Perumahan Rakyat Direktoray Jenderal Cipta Karya, 2016).

Adapun kriteria lokasi untuk program sanimas ini yaitu :

a) Kriteria lokasi sasaran SANIMAS adalah lokasi yang berada di kawasan perkotaan dan semi perkotaan;

b) Berada di daerah pusat pemerintahan, pusat pertumbuhan;

c) Kepadatan Penduduk minimal 150 Jiwa/hektar;

d) Berada di daerah rawan Sanitasi serta memiliki kebutuhan untuk penanganan permasalahan sanitasi sesuai dengan buku dokumen SSK;

e) Diutamakan bagi MBR;

f) Memiliki tingkat Partisipasi masyarakat yang tinggi. 


\section{Derajat Kesehatan Masyarakat}

Berdasarkan pasal 1 angka 1 undangundang nomor 36 tahun 2009 Kesehatan merupakan suatu keadaan yang sehat, baik jasmani, rohani, maupun sosial yang memungkinkan setiap orang untuk hidup produktif secara sosial dan ekonomi. (Undang-Undang, 2009).

Berdasarkan pada jalinan Dokter Amerika (1948) kesehatan warga ialah ilmu serta seni dalam memelihara, melindungi serta tingkatan kesehatan warga lewat upaya pengorganisasian kelompok masyarakat.(Ani Wulandari, 2013).

Menurut Hendril L Blumm dalam (Notoatmojo, 2007) terdapat 4 faktor yang mempengaruhi derajat kesehatan masyarakat, yaitu : Faktor Perilaku, faktor lingkungan, faktor keturunan dan pelayanan kesehatan.

Ada 4 faktor yang mempengaruhi derajat kesehatan masyarakat, yaitu: faktor perilaku, lingkungan, keturunan dan pelayanan kesehatan.

1) Faktor Genetik

Faktor ini paling kecil pengaruhnya terhadap kesehatan perorangan atau masyarakat dibandingkan dengan faktor yang lain.Pengaruhnya pada status kesehatan perorangan terjadisecara evolutif dan paling sukar di deteksi .Untuk itu,perlu dilakukan konseling genetik.

\section{2) Faktor Pelayanan Kesehatan}

Ketersediaan pelayanan kesehatan dan pelayanan kesehatan yang berkualitas akan berpengaruh terhadap derajat kesehatan masyarakat .Pengetahuan dan keterampilan petugas kesehatan yang diimbangi dengan kelengkapan sarana/prasarana,dan dana akan menjamin kualitas pelayanan kesehatan.Pelayanan seperti ini akan mampu mengurangi atau mengatasi masalah kesehatan yang berkembang di suatu wilayah atau kelompok masyarakat.

\section{3) Faktor Prilaku Masyarakat}

Faktor ini terutama di negara berkembang paling besar pengaruhnya terhadap munculnya gangguan kesehatan atau masalah kesehatan masyarakat.Tersedianya jasa pelayanan kesehatan (health service) tanpa disertai perubahan tingkah laku (peran serta) masyarakat akan mengakibatkan masalah kesehatan tetap potensial berkembang di masyarakat.

4) Faktor Lingkungan

Lingkungan yang mendukung gaya hidup bersih juga berperan dalam meningkatkan derajat kesehatan. Dalam kehidupan di sekitar kita dapat kita rasakan, daerah yang kumuh dan tidak dirawat biasanya banyak penduduknya yang mengidap penyakit seperti: gatal-gatal, infeksi saluran pernafasan, dan infeksi saluran pencernaan. Penyakit demam berdarah juga dipengaruhi oleh faktor lingkungan.

\section{METODE PENELITIAN}

Dalam penelitian ini peneliti memakai metode kualitatif dengan pendekatan deskriptif. Penelitian dilakukan di Korong Padang Manis, Nagari Campago Kecamatan V Koto Kampung Dalam Kabupaten Padang Pariaman. Pemilihan informan memakai teknik purposive sampling. Selanjutnya pengumpulan data dilakukan dengan melakukan observasi atau peninjauan, wawancara dan dokumentasi. Unutk menguji keabsahan data dalam penelitian ini yaitu teknik metode dan trangulasi sumber. Sedangkan teknik analisis data dilakukan dengan mereduksi data, menyajikan data sehingga data yang diperoleh dilapangan dapat ditarik kesimpulan.

\section{HASIL DAN PEMBAHASAN}

Berkaitan dengan efektivitas Program sanitasi berbasis masyarakat (sanimas) dalam meningkatkan derajat kesehatan masyarakat diKorong Padang Manis dapat diukur menggunakan 4 indikator yang dikemukakan oleh budiani dalam (Primanda, 2017) yaitu : ketepatan sasaran program, sosialisasi, pencapaian tujuan dan pemantauan. 


\section{Ketepatan Sasaran Program}

Efektivitas suatu program dapat dilihat dari sasaran yang sudah ditetapkan sebelumnya dengan sesudah dilaksanakan program.

Menurut Budiani dalam (Primanda, 2017) mengatakan bahwa efektivitas suatu program dapat dilihat dari ketepatan sasaran program yaitu melihat sejauh mana peserta program tepat dengan sasaran yang sudah ditentukan sebelumnya.

Jika dihubungkan dengan indikator yang dijelaskan oleh Budiani dalam (primanda,2017) maka dapat dikatakan bahwa Untuk melihat sejauh mana ketepatan sasaran program dari pelaksanaan program sanimas dalam meningkatkan derajat kesehatan masyarakat diKorong Padang Manis dilihat dari perencanaan yang dilakukan oleh dinas PUPR Kabupaten Padang Pariaman, dimana dalam pelaksanaan program sanimas dinas PUPR Kabupaten Padang Pariaman bertujuan untuk meningkatkan derajat kesehatan masyarakat serta menerapkan perilaku hidup bersih dan sehat dengan tidak membuang air besar sembarangan terutama dikawasan padat kumuh dan miskin.

Berdasarkan hasil temuan peneliti dilapangan tentang ketepatan sasaran program SANIMAS dikorong Padang Manis dapat disimpulkan cukup efektif. Perihal ini bisa dilihat dari ketepatan target pada program yang mana masih banyak terdapat masyarakat disana yang belum memiliki WC pribadi dan masih banyak juga masyarakat yang belum memiliki tempat pengelolaan air limbal (IPAL) diKorong Padang Manis tersebut.

\section{Sosialisasi Program}

Efektivitas sebuah program dapat dilihat dari aspek sosialisasi program. Sosialisasi program ialah kepiawaian penyelenggara program buat mensosialisasikan program sehingga data tentang penerapan program bisa tersampaikan kepada warga luas serta target pengguna program pada khususnya. Budiani dalam (Primanda, 2017).
Dinas PUPR telah melakukan sosialisasi dikantor walinagari sebelum dilaksanakannya program sanimas dikorong tersebut. Adapun tujuan sosialisasi yang dilakukan mengenai program SANIMAS adalah untuk melihat sesuai atau tidaknya tempat yang dibangun untuk program sanimas, selain itu juga memberikan informasi kepada masyarakat tujuan dari program sanimas.

Berdasarkan hasil temuan peneliti dilapangan mengenai sosialisasi pada program SANIMAS dikorong Padang Manis dapat disimpulkan belum optimal atau efektif. dikarenakan belum seluruhnya diketahui oleh masyarakat karena sosialisasi yang diberikan penyelenggara tidak menyeluruh. Oleh karena itu ada beberapa warga yang tidak mengetahui adanya pihak dinas yang datang melakukan sosialisasi sehingga tidak mengetahui tujuan dari program sanimas ini dan juga tidak mngetahui informasi mengenai program sanimas yang disampaikan oleh pihak dinas.

\section{Pencapaian Tujuan Program}

Efektivitas suatu program dapat dilihat dari aspek Pencapaian tujuan program. adapun maksud dari pencapaian tujuan program itu sendiri menurut Budiani dalam (Primanda, 2017) ialah apakah tujuan dari pelaksanaan program telah sama dengan apa yang sudah direncanakan awalnya.

Program SANIMAS sudah mempunyai tujuan yang jelas ialah menaikkan derajat kesehatan warga. serta meningkatkan kebersihan lingkungan masyarakat. namun dengan apa yang ditemui dilapangan kurang sesuai dengan tujuan yang telah ditetapkan masih ditemui masyarakat yang membuang sampah dan air besar sembarangan serta kurangnya perawatan dan pemeliharaan terhadap program sanimas yang telah ada.

Berdasarkan hasil temuan peneliti dilapangan tentang pencapaian tujuan program terungkap bahwa tujuan yang ingin dicapai belum mencapai target yang telah ditentukan atau dikatakan belum efektif. Hal ini dikarenakan kesadaran 
masyarakat masih rendah akan menjaga kebersihan lingkungan terhadap prasarana program sanimas dan masih ditemukan masyarakat yang membuang sampah dan buang air besar sembarangan jika lingkungan tidak bersih maka sulitnya untuk mencapai meningkatkan derajat kesehatan masyarakat begitu pula dengan data yang diperoleh tidak menampakkan perubahan yang signifikan terhadap kesehatan setelah adanya program sanimas.

\section{Pemantauan Program}

Efektivitas suatu program dapat dilihat dari aspek pemantauan program yaitu kegiatan yang dilakukan setelah dilaksanannya program sebagai bentuk perhatian kepada pemanfaat program. Pemantauan program yang dilakukan oleh pihak pelaksana sangatlah penting karena berpengaruh terhadap kelanjutan program tersebut, dengan adanya pemantaun dari pelaksana maka dapat diketahui apakah tujuan yang diinginkan dari program ini telah tercapai atau tidak. Pemantauan Program Sanitasi berbasis masyarakat (sanimas) dilakukan setelah dilaksanakannya program sebagai bentuk perhatian kepada penerima manfaat dari program sanimas.

Berdasarkan hasil temuan peneliti dilapangan pemantauan yang dilakukan terhadap program sanimas yang telah dibangun belum dapat dikatakan efektif karena tidak adanya jadwal yang dibuat atau belum adanya jadwal tertentu yang dibuat dalam melakukan pemantaun sehingga program sanimas tidak dapat dikatakan efektif.

\section{PENUTUP}

Berdasarkan hasil temuan dilapangan penelitian yang telah dilakukan penulis tentang efektivitas program sanitasi berbasis masyarakat (sanimas) dalam meningkatkan derajat kesehatan masyarakat diKorong Padang Manis, peneliti menilai efektivitas program sanimas diKorong Padang Manis berdasarkan tujuan program belum optimal karena masih terjadinya permasalahan terkait pemeliharaan dan perawatan sarana prasarana sanimas tersebut.

Setelah melakukan penelitian dilapangan berdasarkan 4 indikator menurut teori Budiani maka dapat ditarik kesimpulan : 1). Dari aspek ketepatan sasaran program dapat dikatakan cukup efektif. Dimana dapat dilihat masih banyak masyarakat disana yang belum memiliki WC pribadi dan masih banyak masyarakat yang belum memiliki tempat pengelolaan air limbah sehingga dapat dikatakan daerah tersebut berada didaerah rawan sanitasi. 2). Dari aspek sosialisasi program sanimas diKorong Padang Manis dikatakan belum optimaal atau efektif. Dikarenakan tujuan pada program sanimas belum seluruhnya masyarakat mengetahui karena sosialisasi yang diberikan penyelenggara tidak menyeluruh. 3). Dari aspek pencapaian tujuan program belum mencapai target yang telah ditentukan atau dikatakan belum efektif. Hal ini dikarenakan kesadaran masih rendah akan menjaga akan menjaga kebersihan lingkungan terhadap prasarana program sanimas dan masih ditemukan masyarakat yang membuang sampah dan air besar sembarangan jika lingkungan tidak bersih maka sulitnya untuk mencapai meningkatkan derajat kesehatan masyarakat begitu pula dengan data yang diperoleh tidak menampakkan adanya perubahan yang signifikan terhadap kesehatan masyarakat setelah adanya program sanimas.4). dari aspek pemantauan belum dapat dikatakan efektif karena pemantauan oleh KPP seharusnya dilakukan tiga bulan sekali namun kenyataan dilapangan pemantauan dilakukan tidak menentu atau bisa dikatakan tidak adanya pemantauan yang teratur shingga program sanimas tidak dapat dikatakan efektif.

\section{DAFTAR KEPUSTAKAAN}

Ani Wulandari. (2013). Efektivitas Media Komunikasi M-Radio Kota

Samarinda. eJournal Ilmu 
Ani Saskia, Jumiatil Efektivitas Program Sanitasi Berbasis Masyarakat dalam Meningkatkan Derajat Kesehatan Masyarakat

Komunikasi, 1(1), 389-410.

Dunn, William, N. (2003). Pengantar Analisis Kebijakan Pulblik by William N. Dunn (z-lib.org).pdf.

Hasanah, L. (2018). Efektivitas

Penggunaan sarana Sanitasi Berbasis Masyarakat (SANIMAS) dengan perubahan Perilaku Hidup Bersih dan Sehat di Desa Kecamatan Bluto Kabupaten Sumenep. 7-12.

Kementerian Pekerjaan Umum dan Perumahan Rakyat Direktoray Jenderal Cipta Karya. (2016). Petunjuk Teknik SANIMAS IDB (p. 125).

Notoatmojo. (2007). Kesehatan Masyarakat Ilmu dan Seni. Rineka kerja.

PerPres. (2014). Peraturan Presiden Nomor 185 Tahun 2014 tentang Percepatan Penyediaan Air Minum \& Sanitasi.

Primanda, R. (2017). Efektivitas Program SMS Gateway Pada Masyarakat Oleh Dinas Kependudukan dan Pencatatan Sipil Kabupaten Bintan. Efektivitas Program SMS Gateway Pada Masyarakat Oleh Dinas Kependudukan Dan Pencatatan Sipil Kabupaten Bintan, 5(2), 1-7.

Rosalina, I. (2012). Efektivitas Program Nasional Pemberdayaan Masyarakat Mandiri Karangrejo Kabupaten Magetan. Fakultas Ilmu Sosial Dan Hukum Universitas Surabaya, 1, 0216.

Undang-Undang. (2009). Undang-Undang Republik Indonesia Nomor 36 Tahun 2009 Tentang Kesehatan (Vol. 4, Issue $3)$.

Undang-Undang. (2014). Undang-Undang Republik Indonesia Nomor 23 Tahun
2014 Tentang Pemerintahan Daerah. In Implementation Science (Vol. 39, Issue 1, pp. 1-15). 